\title{
Multiple isolated extramedullary relapse of acute promyelocytic leukemia after allogeneic hematopoietic stem cell transplant: a case report and review of literature
}

\author{
Shalin Kothari ${ }^{*}$, Geoffrey Herzig ${ }^{1}$, Stephen Slone ${ }^{2}$ and Roger Herzig ${ }^{1}$
}

\begin{abstract}
Isolated extramedullary disease (EMD) is uncommon, especially in acute promyelocytic leukemia (APL) after allogeneic hematopoietic stem cell transplantation (HSCT). We review the literature and present a 32 year old woman with APL who developed multiple EMDs after allogeneic HSCT within the calvarium, and later found to have various isolated lesions including femur, humerus and thoraco lumbar vertebrae. She was treated with local radiotherapy (XRT) to EMD lesions, all-trans retinoic acid, arsenic trioxide and donor lymphocyte infusion at different time points in her clinical course, without success. Out of reported cases in clinical setting as ours, average onset of isolated EMD is 25 months and median survival 14 months. Effective treatment of isolated EMD after HSCT is not yet clear, but ATO in combination with local XRT, tamibarotene and second HSCT have shown good results in some reported cases, but accumulation of more cases is needed to elucidate optimal therapy in such setting.
\end{abstract}

\section{Introduction}

Among the more treatable subtypes of acute myeloid leukemia (AML) is acute promyelocytic leukemia (APL). Nearly all patients with APL have a translocation of chromosomes 15 and 17, resulting in the fusion between RAR $\alpha$ (retinoic acid receptor $\alpha$ ), which encodes a retinoic acid receptor, and the promyelocytic leukemia (PML) protein (Licht 2009). "Myeloid sarcoma", a solid extramedullary mass composed of immature myeloid cells, was first described by Burns in 1811 (Burns 1823). King (1853) used the term "chloroma" because of its greenish appearance, caused by myeloperoxidase in the leukemic cells (King 1853). Although myeloid sarcomas usually appear as a manifestation of systemic leukemias, they occasionally precedea marrow relapse and may be the presenting finding (Mwanda and Rajab 1999). We present a case of multiple skull lesions of myeloid sarcoma in a patient with APL that occurred seven months

\footnotetext{
* Correspondence: s0koth02@cardmail.louisville.edu

'Division of Blood and Bone Marrow Transplant, University of Louisville, James Graham Brown Cancer Center, 529 South Jackson Street, Louisville, KY 40202, USA

Full list of author information is available at the end of the article
}

after allogeneic hematopoietic stem cell transplant (HSCT). For the rest of this review, myeloid sarcomas will be referred to as extramedullary disease (EMD).

\section{Case report}

The patient, a 32 year-old woman, was diagnosed with APL (bcr1 subtype) and treated at an area hospital with standard oral all-trans retinoic acid (ATRA), cytarabine and idarubicin induction with initial complete remission (CR). She maintained CR status for 18 months with 2 courses of consolidation therapy consisting of idarubicin and cytarabine. However, she relapsed in BM and CNS while being on ATRA as maintenance therapy. She had a successful re-induction with arsenic trioxide (ATO) and intrathecal cytarabine followed by high-dose busulfan and etoposide with autologous PML/RAR $\alpha$ PCR-negative hematopoietic cells rescue. She relapsed in 7 months and was referred to our institution for an allogeneic HSCT from her HLA matched sister after cyclophosphamide and total body irradiation (TBI) conditioning regimen. She achieved full donor chimerism with no molecular evidence of disease. Seven months later, she presented with right 
fronto-parietal headaches and also noticed a "bump" over the right frontal area.

Magnetic resonance imaging (MRI) showed multiple enhancing lesions within the calvarium, with most prominent lesion in right frontal bone, measuring $2.0 \times$ $0.9 \mathrm{~cm}$ that were not present on MRI done before allogeneic HSCT (Figure 1). The lesions were iso- to slightly hypointense on T1 and isointense on T2-weighted images. Subsequent skeletal survey and whole body PET/CT imaging showed multiple bony lesions involving frontal and parietal bones, bilateral glenoid fossae, proximal left femur, distal left humerus and T5, T9 and L4 vertebral bodies.

Biopsy of right frontal lesion revealed EMD that expressed CD45 (dim to moderate), CD34 and CD117 (focal weak); and did not express CD56 and CD68. Fluorescent in-situ hybridization (FISH) identified 22 out of 50 cells positive for PML/RAR $\alpha$ translocation. It was clear that these EMD lesions were secondary to her APL. Iliac crest bone marrow biopsy showed no morphologic evidence of leukemia and chimerism evaluation by microsatellite polymorphisms showed $100 \%$ of cells of donor origin; peripheral blood PCR for PML/RARA transcript was negative.

Post-transplant immunosuppression was discontinued; she was treated with ATRA, intrathecal methotrexate, and radiation therapy (XRT) to skull and proximal left femur. After radiation therapy (a total of 20 Gy in 10 fractions), she received two months of ATO, but had progressive disease evident on whole body PET/CT imaging. She was then treated with high-dose cytarabine and idarubicin with infusion of stored donor hematopoietic cells (DLI), but died of complications 16 days after starting therapy. CT scan of head without contrast done day the before her death re-demonstrated the skull lesions.

Figure 2 includes a summary of clinical course of our patient.

\section{Discussion}

In this report, we present a patient with CD56 negative APL after allogeneic HSCT who developed multiple EMD without BM relapse (isolated EMD) early in her
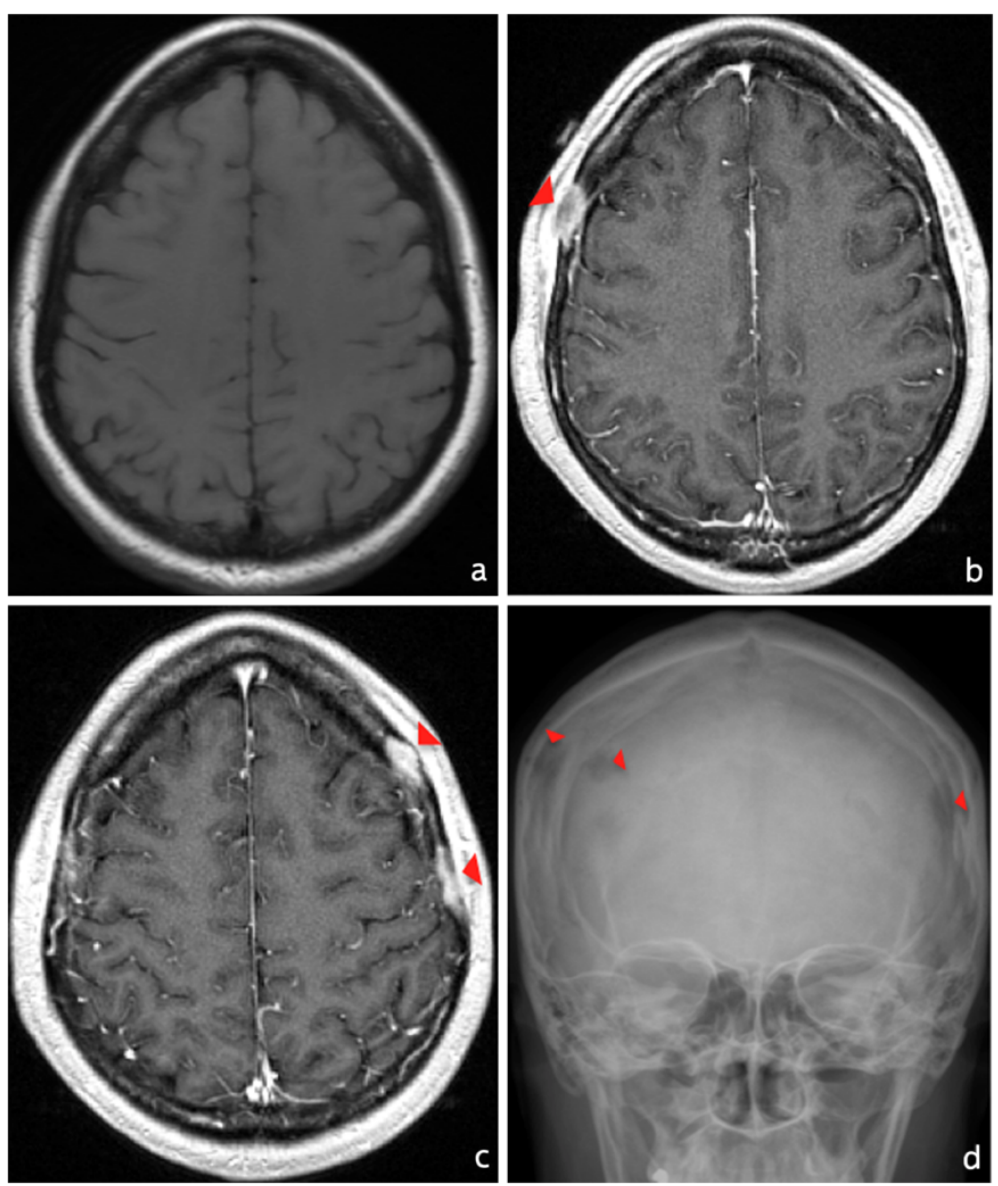

Figure 1 a- Normal pre-allogeneic HSCT MRI of brain. $\mathbf{b}$ and $\mathbf{c}-$ Post contrast 3D spoiled gradient echo showing numerous thickened contrast enhancing lesions measuring up to $1.6 \times 0.8 \mathrm{~cm}$ in the left frontal, $2.0 \times 0.9 \mathrm{~cm}$ in the right frontal and $2.7 \times 0.5 \mathrm{~cm}$ in the left parietal region, within the calvarium. $\mathbf{d}$ - $X$-ray of skull, frontal view showing lytic lesions in the frontal and parietal bones. 


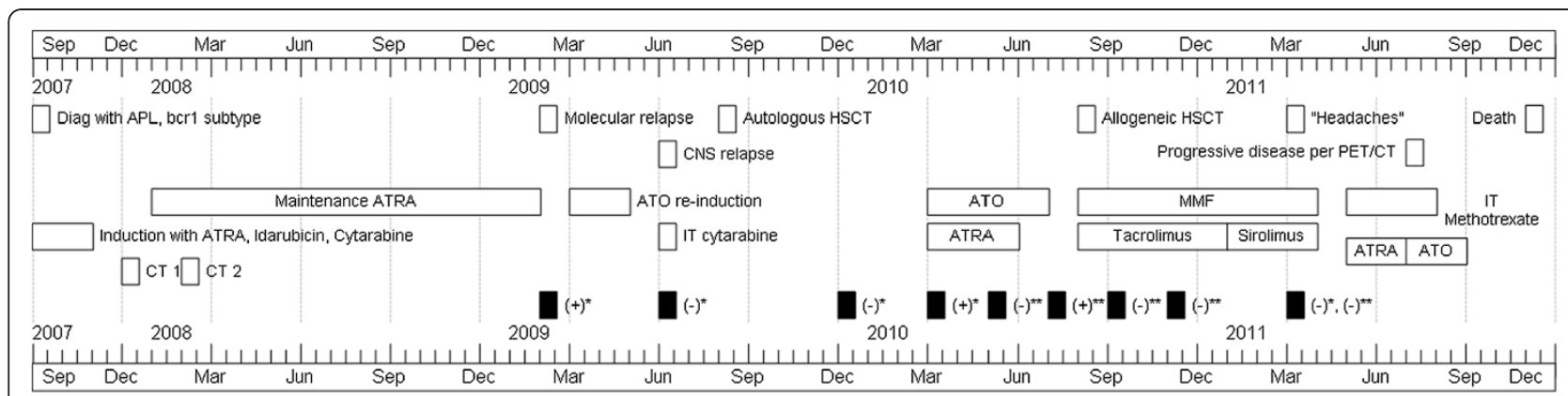

Figure 2 Timeline of course of disease and treatment. - PML/RARa transcript. *- in bone marrow by PCR, **- in peripheral blood. Diag- Diagnosed, APL- Acute promyelocytic leukemia, HSCT- Hematopoietic stem cell transplantation, dz- disease, CNS- Central nervous system, ATRA- All-trans retinoic acid, ATO- Arsenic trioxide, MMF- Mycophenolate mofetil, IT- Intra-thecal, CT- Consolidation therapy.

post-transplant course. She was treated with local XRT to EMD lesions, ATRA, ATO and DLI at different points of time, without success.

In general, isolated EMD of acute myeloid leukemia (AML), following allogeneic HSCT is uncommon, and occurs in about $0.65 \%$ of all HSCT cases as estimated from the European BM Transplant Registry, with higher rates of up to 10\% reported in long-term survivors (Bekassy et al. 1996). In contrast to our patient, who remained in molecular and hematologic remission for five months after isolated EMD, most isolated extramedullary relapses portend BM relapse (Ruiz-Arguelles et al. 2005).

There have been 12 reported cases, including ours, of isolated EMD with APL after HSCT (Table 1). Among them, reported sites of EMD are skin, testes, bone, CNS, spine, psoas muscle, middle ear, scalp, breast, nasal cavity, pharynx and bowel. There is no obvious conclusion to site predilection.

Average onset of EMD after HSCT in APL patients is 19 months, ranging from 7 months to 54 months. Our

Table 1 Reported cases of acute promyelocytic leukemia with EMD after HSCT

\begin{tabular}{|c|c|c|c|c|c|}
\hline Case report & $\begin{array}{c}\text { TBI-containing } \\
\text { conditioning regimen? }\end{array}$ & $\begin{array}{l}\text { Onset of EMD } \\
\text { after HSCT }\end{array}$ & $\begin{array}{l}\text { Treatment tried at various time points for } \\
\text { EMD }\end{array}$ & $\begin{array}{l}\text { BM status after } \\
\text { treatment }\end{array}$ & $\begin{array}{l}\text { Patient status } \\
\text { after EMD }\end{array}$ \\
\hline \multirow[t]{3}{*}{$\begin{array}{l}\text { (Bekassy et al. } \\
\text { 1996) }\end{array}$} & No & $54 \mathrm{mo}$ & Local XRT, surgical resection, $C^{*}$ & $\begin{array}{l}\text { Relapse after } 5 \\
\text { mo }\end{array}$ & Alive at $15 \mathrm{mo}$ \\
\hline & Yes & $28 \mathrm{mo}$ & Local XRT, surgical resection, $C T^{*}$ & $\begin{array}{l}\text { Relapse after } 11 \\
\text { mo }\end{array}$ & Death at 14 mo \\
\hline & No & $20 \mathrm{mo}$ & Local XRT, CT* & $\begin{array}{l}\text { Relapse after } 1 \\
\text { mo }\end{array}$ & Death at $1 \mathrm{mo}$ \\
\hline $\begin{array}{l}\text { (Forrest et al. } \\
\text { 1997) }\end{array}$ & No & $48 \mathrm{mo}$ & Local XRT, ATRA, Ara-C, DNR & Remission & Death at $25 \mathrm{mo}$ \\
\hline $\begin{array}{l}\text { (Milone et al. } \\
\text { 1999) }\end{array}$ & No & $9 \mathrm{mo}$ & Etoposide, whole skin XRT, DLI & Remission & NM \\
\hline $\begin{array}{l}\text { (Ustun et al. } \\
\text { 2001) }\end{array}$ & NM & $13 \mathrm{mo}$ & ATRA, local XRT & Remission & Alive at $19 \mathrm{mo}$ \\
\hline $\begin{array}{l}\text { (Classen et al. } \\
\text { 2003) }\end{array}$ & No & $18 \mathrm{mo}$ & $\begin{array}{l}\text { DNR; ATRA; Topotecan; intrathecal MTX, } \\
\text { prednisolone, Ara-C; } 2^{\text {nd }} \mathrm{HSCT}\end{array}$ & Remission & Alive at $43 \mathrm{mo}$ \\
\hline $\begin{array}{l}\text { (Ammatuna } \\
\text { et al. 2005) }\end{array}$ & NM & $36 \mathrm{mo}$ & GO, Local XRT, DLI, ATO & $\begin{array}{l}\text { Relapse after } 7 \\
\text { mo }\end{array}$ & Alive at $13 \mathrm{mo}$ \\
\hline (Kai et al. 2006) & Yes & $14 \mathrm{mo}$ & ATO, Local XRT & Remission & Alive at $20 \mathrm{mo}$ \\
\hline $\begin{array}{l}\text { (Naina et al. } \\
\text { 2011) }\end{array}$ & No & $31 \mathrm{mo}$ & GO, ATRA, tamibarotene & Remission & Alive at $12 \mathrm{mo}$ \\
\hline $\begin{array}{l}\text { (Ochs et al. } \\
\text { 2010) }\end{array}$ & No & $25 \mathrm{mo}$ & Surgical resection, ATRA, Local XRT & Relapse "shortly" & Death at 4 mo \\
\hline Our case & Yes & $7 \mathrm{mo}$ & ATRA, intrathecal MTX, local XRT, ATO, DLI & Remission & Death at $8 \mathrm{mo}$ \\
\hline
\end{tabular}

TBI- Total-body irradiation, EMD- Extramedullary disease, HSCT- Hematopoietic stem cell transplantation, $B M$ - Bone marrow, $X R T$ - radiotherapy, $C T^{*}$ - Specifics of chemotherapy not described, mo- months, ATRA- All-trans retinoic acid, Ara-C-Cytarabine, DNR- Daunorubicin, DLI- Donor lymphocyte infusion, NM- Not mentioned, MTX- Methotrexate, GO- Gemtuzumab ozogamicin, ATO- Arsenic trioxide. 
patient presented within 7 months of allogeneic HSCTthe earliest of reported cases with EMD. Significance of such wide range of onset remains unknown.

There are no known risk factors for EMD (Kai et al. 2006), but several have been postulated. Some authors have suggested an increase in the incidence of EMD since the introduction of ATRA in the treatment of APL. Modulation of APL blasts and endothelial cells adhesion molecules, and upregulation of the granulocytecolony stimulating factor receptor are some of the proposed mechanisms (de Botton et al. 2006; Weiss and Warrell 1994; Wiernik et al. 1996). The expression of CD56 has been associated with an increase in EMD and resistance to ATRA and anthracycline therapy (Montesinos et al. 2011). The role of ATRA in the development of EMD in APL remains controversial, especially in CD56 negative EMD, as in our case (Ito et al. 2004). Given the universal use of ATRA in APL and the rarity of EMDs, ATRA seems to have only a small role, if any, in development of EMDs. Kai et al. speculated that nonTBI containing regimens might increase the risk for EMD after HSCT in APL (Kai et al. 2006). Since only three of the reported cases received TBI-containing regimen, more cases need to be analyzed to elucidate the role of conditioning regimen as a risk factor for EMD. It has also been suggested that certain ethnic groups may be at higher risk of EMD in APL (Wiernik et al. 1996). Some investigators suggested that tissue injury caused by diagnostic procedures and bleeding leads to occurrence of EMD via leakage of leukemic cells, growth factors, and cell mediators (Sanz et al. 2000). Except for ATRA, our patient did not have any of these proposed risk factors.

Biopsy is the most preferred diagnostic method for EMD. Our biopsy result differs from the observation of Pileri et al. and Campidelli et al. (Campidelli et al. 2009; Pileri et al. 2007), in that, EMD, in our case, did not express CD68/KP1. The vast majority of normal CD34 positive hematopoietic precursors are CD68 negative, whereas AML CD34 positive blasts are usually CD68 positive. CD68 epitopes have been suggested as a potential target for leukemia-reactive cytotoxic-T cell (Sadovnikova et al. 2002). But, patients such as ours may not benefit from such therapy.

Bony EMD lesions appear lytic rather than sclerotic (Libson et al. 1986; Cho et al. 1990). On MRI, they are typically iso- to slightly hypointense on T1- and isointense on T2-weighted images relative to brain tissue (Kao et al. 1987). Both CT scan and MRI are diagnostically very useful, but MRI better reveals the exact extent of the tumor and the potential invasion of the cranial nerve or a intracranial structure (Chang et al. 2009).

As evident from Table 1, BM status after EMD has little influence on patient survival. Our patient remained in $\mathrm{CR}$ and showed $100 \%$ donor chimerism even though she succumbed to her progressive disease within 8 months.

During the course of APL, recognition of EMD is important as aggressive induction chemotherapy or XRT can induce CR. Several treatment options for isolated EMD after allogeneic HSCT in APL patients have been postulated, which include local XRT, ATRA, tamibarotene (earlier known as Am80), ATO, DLI, or a second allogeneic HSCT (Kai et al. 2006). Successful treatment was documented with gemtuzumab ozogamicin (Mylotarg) by many authors before FDA withdrew it in 2010 (Cohen et al. 2002; Ando et al. 2010). Treatment tried in the reported cases of post-HSCT EMDs in APL patients are summarized in Table 1 . The combination therapy of ATO and XRT for APL EMDs may be reasonable, since enhancement of sensitivity to XRT by ATO treatment has been reported for some kind of solid tumors (Griffin et al. 2005), though, as evident from Table 1, treatment with ATO and local XRT has not been fully explored in such setting. The longest survivor had a second allogeneic HSCT, suggesting that this approach may be the only curative one.

Although long-term survival has occasionally been achieved, the prognosis for EMD patients is generally poor, particularly when they occur during remissions and after HSCT (Bekassy et al. 1996). Median survival after EMD in such setting is 14 months (range: 1-43 months).

\section{Conclusion}

EMD is uncommon, especially in APL after treatment. Average onset of isolated EMD after HSCT in APL patients is 25 months. The role of ATRA in development of EMDs needs to be elucidated, especially in CD56 negative cases. Despite graft versus host disease and the potential graft versus leukemia effect, our patient had EMD and maintained 100\% donor chimerism. In setting as our patient's, BM status after EMD has little influence, if at all, in overall patient survival. There is a potential for research in novel therapies targeting surface markers, especially in CD68 negative myeloid cells. Treatment of isolated EMD after HSCT remains a challenge. ATO and local XRT have shown good response in some reports but a second allogeneic HSCT may be needed for long-term survival.

\section{Competing interests}

The authors declare that they have no competing interests.

\section{Authors' contributions}

SK carried out the patient chart review, reviewed the current literature and drafted the manuscript. $\mathrm{GH}$ and $\mathrm{RH}$ provided with scientific conclusions after analysis of the case report and reviewed literature, and edited the manuscript. SS reviewed and analyzed the biopsy, immunostaining and PCR results for our case. All authors read and approved the final manuscript. 


\section{Author details}

'Division of Blood and Bone Marrow Transplant, University of Louisville, James Graham Brown Cancer Center, 529 South Jackson Street, Louisville, KY 40202, USA. ${ }^{2}$ Department of Pathology and Laboratory Medicine, University of Louisville, Louisville, KY 40292, USA.

Received: 18 October 2012 Accepted: 9 February 2013

Published: 12 February 2013

\section{References}

Ammatuna E, Borza PA, lori AP, Petti MC, Pescarmona E, Diverio D, Lo-Coco F (2005) Multiple relapses and extramedullary localization with scalp and breast involvement in a case of acute promyelocytic leukaemia. Leukemia 19 (3):479-480. doi:10.1038/sj.leu.2403632

Ando T, Mitani N, Matsunaga K, Nakazora T, Gondo T, Yujiri T, Tanizawa Y (2010) Gemtuzumab ozogamicin therapy for isolated extramedullary AML relapse after allogeneic hematopoietic stem-cell transplantation. Tohoku J Exp Med 220(2):121-126

Bekassy AN, Hermans J, Gorin NC, Gratwohl A (1996) Granulocytic sarcoma after allogeneic bone marrow transplantation: a retrospective european multicenter survey. Acute and chronic leukemia working parties of the European group for blood and marrow transplantation. Bone Marrow Transplant 17(5):801-808

Burns A (1823) Observations on the surgical anatomy of the head and neck. In: Pettison GS (ed) 4 edn. Baltimore, USA

Campidelli C, Agostinelli C, Stitson R, Pileri SA (2009) Myeloid sarcoma: extramedullary manifestation of myeloid disorders. Am J Clin Pathol 132 (3):426-437. doi:10.1309/AJCP1ZA7HYZKAZHS

Chang KH, Kim DK, Jun BC, Park YS (2009) Temporal bone myeloid sarcoma. Clin Exp Otorhinolaryngol 2(4):198-202. doi:10.3342/ceo.2009.2.4.198

Cho JS, Kim EE, Ro JH, Pinkel DP, Goepfert H (1990) Mandibular chloroma demonstrated by magnetic resonance imaging. Head Neck 12(6):507-511

Classen CF, Debatin KM, Friedrich W, Schulz AS (2003) Long-term remission of APL with a second allogeneic BMT after CNS relapse following HLA-identical allogeneic BMT. Bone Marrow Transplant 32(8):843-846. doi:10.1038/sj. bmt.1704225

Cohen AD, Luger SM, Sickles C, Mangan PA, Porter DL, Schuster SJ, Tsai DE, Nasta S, Gewirtz AM, Stadtmauer EA (2002) Gemtuzumab ozogamicin (Mylotarg) monotherapy for relapsed AML after hematopoietic stem cell transplant: efficacy and incidence of hepatic veno-occlusive disease. Bone Marrow Transplant 30(1):23-28. doi:10.1038/sj.bmt.1703602

de Botton S, Sanz MA, Chevret S, Dombret H, Martin G, Thomas X, Mediavilla JD Recher C, Ades L, Quesnel B, Brault P, Fey M, Wandt H, Machover D, Guerci A, Maloisel F, Stoppa AM, Rayon C, Ribera JM, Chomienne C, Degos L, Fenaux P (2006) Extramedullary relapse in acute promyelocytic leukemia treated with all-trans retinoic acid and chemotherapy. Leukemia 20(1):35-41. doi:10.1038/sj.leu.2404006

Forrest DL, Dalal BI, Naiman SC, Horsman DE, Berry BR, Parslow MI, Singh CP, Benny WB, Barnett MJ (1997) Testicular relapse of acute promyelocytic leukemia after allogeneic BMT. Bone Marrow Transplant 20(8):689-690. doi:10.1038/sj.bmt.1700948

Griffin RJ, Williams BW, Park HJ, Song CW (2005) Preferential action of arsenic trioxide in solid-tumor microenvironment enhances radiation therapy. Int J Radiat Oncol Biol Phys 61(5):1516-1522. doi:10.1016/j.ijrobp.2004.12.058

Ito S, Ishida Y, Oyake T, Satoh M, Aoki Y, Kowata S, Uchiyama T, Enomoto S, Sugawara T, Numaoka H, Suzuki K, Murai K (2004) Clinical and biological significance of CD56 antigen expression in acute promyelocytic leukemia. Leuk Lymphoma 45(9):1783-1789. doi:10.1080/10428190410001683624

Kai T, Kimura H, Shiga Y, Ogawa K, Sato H, Maruyama Y (2006) Recurrent extramedullary relapse of acute promyelocytic leukemia after allogeneic stem cell transplantation: successful treatment by arsenic trioxide in combination with local radiotherapy. Int J Hematol 83(4):337-340. doi:10.1532/IJH97.05167

Kao SC, Yuh WT, Sato Y, Barloon TJ (1987) Intracranial granulocytic sarcoma (chloroma): MR findings. J Comput Assist Tomogr 11(6):938-941

King A (1853) A case of chloroma. Monthly J Med Soc 17:97

Libson E, Bloom RA, Galun E, Polliack A (1986) Granulocytic sarcoma (chloroma) of bone: the CT appearance. Comput Radiol 10(4):175-178

Licht JD (2009) Acute promyelocytic leukemia-weapons of mass differentiation. N Engl J Med 360(9):928-930. doi:10.1056/NEJMcibr0810371
Milone G, Inghilterra G, Li Gioi F, Peluso D, Giustolisi R (1999) Testicular and cutaneous relapse after hematopoietic transplantation in a patient affected with APL. Bone Marrow Transplant 23(7):751. doi:10.1038/sj.bmt.1701625

Montesinos P, Rayon C, Vellenga E, Brunet S, Gonzalez J, Gonzalez M, Holowiecka A, Esteve J, Bergua J, Gonzalez JD, Rivas C, Tormo M, Rubio V, Bueno J, Manso F, Milone G, de la Serna J, Perez I, Perez-Encinas M, Krsnik I, Ribera JM, Escoda L, Lowenberg B, Sanz MA (2011) Clinical significance of CD56 expression in patients with acute promyelocytic leukemia treated with alltrans retinoic acid and anthracycline-based regimens. Blood 117(6):17991805. doi:10.1182/blood-2010-04-277434

Mwanda WO, Rajab JA (1999) Granulocytic sarcoma: report of three cases. Eas Afr Med J 76(10):594-596

Naina HV, Levitt D, Vusirikala M, Anderson LD Jr, Scaglioni PP, Kirk A, Collins RH Jr (2011) Successful treatment of relapsed and refractory extramedullary acute promyelocytic leukemia with tamibarotene. J Clin Oncol 29(18):e534-e536. doi:10.1200/JCO.2011.34.8953

Ochs RC, Gormley RH, Luger S, Bagg A (2010) Isolated bowel relapse in acute promyelocytic leukemia: an unusual site of extramedullary recurrence. J Clin Oncol 28(29):e550-e553. doi:10.1200/JCO.2010.29.7424

Pileri SA, Ascani S, Cox MC, Campidelli C, Bacci F, Piccioli M, Piccaluga PP, Agostinelli C, Asioli S, Novero D, Bisceglia M, Ponzoni M, Gentile A, Rinaldi P, Franco V, Vincelli D, Pileri A Jr, Gasbarra R, Falini B, Zinzani PL, Baccarani M (2007) Myeloid sarcoma: clinico-pathologic, phenotypic and cytogenetic analysis of 92 adult patients. Leukemia 21(2):340-350. doi:10.1038/sj. leu. 2404491

Ruiz-Arguelles GJ, Gomez-Almaguer D, Vela-Ojeda J, Morales-Toquero A, Gomez Rangel JD, Garcia-Ruiz-Esparza MA, Lopez-Martinez B, Cantu-Rodriguez OG, Gutierrez-Aguirrec CH (2005) Extramedullary leukemic relapses following hematopoietic stem cell transplantation with nonmyeloablative conditioning. Int J Hematol 82(3):262-265. doi:10.1532/IJH97.04195

Sadovnikova E, Parovichnikova EN, Savchenko VG, Zabotina T, Stauss HJ (2002) The CD68 protein as a potential target for leukaemia-reactive CTL. Leukemia 16(10):2019-2026. doi:10.1038/sj.leu.2402635

Sanz MA, Larrea L, Sanz G, Martin G, Sempere A, Gomis F, Martinez J, Regadera A, Saavedra S, Jarque I, Jimenez C, Cervera J, de La Rubia J (2000) Cutaneous promyelocytic sarcoma at sites of vascular access and marrow aspiration. A characteristic localization of chloromas in acute promyelocytic leukemia? Haematologica 85(7):758-762

Ustun C, Arat M, Celebi H, Akan H, Ilhan O, Ozcelik T, Burgess RE, Koc H (2001) Extramedullary relapse following allogeneic stem cell transplantation in acute promyelocytic leukemia: the role of ATRA. Haematologica 86(10):E31

Weiss MA, Warrell RP Jr (1994) Two cases of extramedullary acute promyelocytic leukemia. Cytogenetics, molecular biology, and phenotypic and clinical studies. Cancer 74(7):1882-1886

Wiernik PH, De Bellis R, Muxi P, Dutcher JP (1996) Extramedullary acute promyelocytic leukemia. Cancer 78(12):2510-2514

doi:10.1186/2193-1801-2-49

Cite this article as: Kothari et al:: Multiple isolated extramedullary relapse of acute promyelocytic leukemia after allogeneic hematopoietic stem cell transplant: a case report and review of literature. SpringerPlus 2013 2:49.

\section{Submit your manuscript to a SpringerOpen ${ }^{\odot}$ journal and benefit from:}

- Convenient online submission

- Rigorous peer review

- Immediate publication on acceptance

- Open access: articles freely available online

- High visibility within the field

- Retaining the copyright to your article

Submit your next manuscript at $>$ springeropen.com 